\title{
Synthesis And Antibacterial Activities of Benzothiazole Derivatives of Sulphonamides
}

\author{
Chinyere B. C. Ikpa a, Samuel 0. Onoja ${ }^{b *}$, Anastasia 0. Okwaraji a \\ aDepartment of Chemistry, Imo State University Owerri, Imo State Nigeria \\ bDepartment of Veterinary Physiology and Pharmacology, Michael Okpara University of Agriculture Umudike, PMB 7267, Abia State, Nigeria \\ *Corresponding Author email: onoja.samuel@mouau.edu.ng; samonreal@yahoo.com, Phone: +2348030613032
}

\section{DOI: 10.2478/acmy-2020-0009}

\begin{abstract}
:
This study aims to synthesize hybrid compounds "via" the coupling of sulphonamide and benzothiazole into one structure that may have improved antibacterial property. The N-(biphenyl-4-yl) thiourea (1) used for the synthesis of the targeted sulphonamides was obtained by reacting diphenylamine and ammonium thiocyanate at room temperature. Cyclization of N-(biphenyl-4-yl)thiourea gave 2-amino-6-phenylbenzothiazole (2) which reacted with benzenesulphonyl chloride and para-toulene sulphonyl chloride to give the targeted sulphonamides (3a \& 3b). The synthesized compounds were characterised using melting point, infra-red spectroscopy, nuclear magnetic resonance and elemental analysis. Anti-bacterial screening of the synthesised compounds indicated that all the compounds showed anti-bacterial properties, except 2-amino-6-phenylbenzothiazole that did not show any activity on Escherichia coli.
\end{abstract}

Keywords: Antibacterial, Benzothiazole Derivatives, Sulphonamide, Synthesis, Thiourea

\section{Introduction:}

Antibacterial resistance is a global public health problem that has hampered the effective prevention and treatment of wide range of bacterial diseases $[1,2]$. Antibacterial resistance is aggravated by the misuse or overuse of antibacterial agents in people and animal [3]. Some bacteria are multidrug resistant and the major examples are Staphylococcus aureus and Escherichia coli [3]. These multidrug resistant organisms have increased the cost of healthcare "via" prolonged stay in hospital and more intensive care [2]. World Health Organisation (WHO) reported that the death caused by methicillin resistant S. aureus infection is higher by $64 \%$ as against the non-methicillin resistant $S$. aureus infection [2].

One of the WHO strategies for the control of antimicrobial resistance is to encourage investment in new medicine research and development [4]. In accordance with this recommendation many research team are engrossed in the synthesis of new antimicrobial drug with better efficacy and lower toxicity [2,5]. The most exploited derivatives are sulphonamides, thiourea and benzothiazole [6]. The antimicrobial, antioxidant, antiviral and antitumor properties of thiourea derivatives have been reported [3,6]. Sulphonamide derivatives with antimicrobial, analgesic, anti-inflammatory, antitumor and antimalarial activities have been documented [6-9]. Benzothiazole derivatives are heterocyclic compounds with diverse biological activities such as antimicrobial, anticancer, antidiabetic, anti-inflammatory and analgesic activities [10]. Despite the vast number of antimicrobial agent available for the treatment of microbial infection, the problems of antimicrobial resistance is yet to be resolved. This study aims to synthesize hybrid compounds via the coupling of sulphonamide and benzothiazole into one structure that may have improved antibacterial property.

\section{Materials and Methods}

The chemicals used were of analytical grade and used without further purification. Melting points were determined with an open capillary melting point apparatus and are uncorrected. Reaction completion was monitored with thin layer chromatography (TLC) using silica gel-G (Marck 60). All the compounds were purified by column chromatography using silica gel mesh 120-160 (Marck). Infrared spectrophotometer was recorded on FT-IR (KBr) cm-1 at National Research Institute for Chemical Technology Zaria (NARICT) with Shimazu FT-IR 8400s as described by Chinaka and Coworkers [11]. ${ }^{1} \mathrm{H}$ and ${ }^{13} \mathrm{C}$ of compounds 1 and 2 were recorded in $\mathrm{CDCl}_{3}$ on Agillant $\mathrm{f} 1$ spectrometer at Central Laboratory of Kwame Nkrummah University of Science and Technology Ghana while ${ }^{1} \mathrm{H}$ and ${ }^{13} \mathrm{C}$ of compounds $3 \mathrm{a} \& 3 \mathrm{~b}$ were recorded in $\mathrm{CDCl}_{3}$ on Brucker WM $300 \mathrm{f} 1$ and $300 \mathrm{f} 2$ spectrometer at Central Drug Research Institute Lucknow India as described by Chinaka and Coworkers [11].

\subsection{Synthesis of $\mathrm{N}$-(biphenyl-4-yl)thiourea (1)}

A solution of $2 \mathrm{~g}$ of diphenylamine and $2 \mathrm{~g}$ of ammonium thiocyanate in $15 \mathrm{~mL}$ of methanol was stirred at room temperature until the salt dissolved and became light brown in colour. On completion of the reaction which was monitored with TLC, $2 \mathrm{M} \mathrm{H}_{2} \mathrm{SO}_{4}$ was added until the pH of the solution was 2. The orange colour precipitate obtained was filtered with suction pressure and crystallized with water. Yield of $56 \%(1.12 \mathrm{~g}) ; \mathrm{mp} \mathrm{of} 56-58^{\circ} \mathrm{C} ; \mathrm{FT}-\mathrm{IR}(\mathrm{KBr}) \mathrm{cm}^{-1}$ gave absorption bands at $1527.67 \mathrm{~m}\left(-\mathrm{NH}_{2}\right), 2576.98 \mathrm{w}(-\mathrm{SH}), 1719.60(\operatorname{aryl})$ and $2265.47(\mathrm{~N}=\mathrm{C}-\mathrm{S})$. Proton spectrum $\left(\delta^{1} \mathrm{H}\right): 7.49\left(\mathrm{CDCl}_{3}\right), 7.99(\mathrm{Ar}-\mathrm{H}, \mathrm{J}=$ 0.96), $3.55(\mathrm{SH})$ and $2.46\left(\mathrm{NH}_{2}\right) . \delta^{13} \mathrm{C}: 126.73,128.36,129.28(\mathrm{Ph}-\mathrm{C}), 129.71(\mathrm{C}-\mathrm{NH})$ and $143.00(\mathrm{C}-\mathrm{NH})$. Analytical Calculated: for $\mathrm{C}_{13} \mathrm{H}_{12} \mathrm{~N}_{2} \mathrm{~S}: \mathrm{C}=68.39 ; \mathrm{H}=$ 5.31; $\mathrm{N}=12.27$; Found: $\mathrm{C}=68.32 ; \quad \mathrm{H}=5.19 ; \mathrm{N}=12.15$.

\subsection{Synthesis Of 2-Amino-6-Phenylbenzothiazole (2)}

A freshly prepared solution of bromine gas in $20 \mathrm{~mL}$ chloroform at the temperature of $0^{\circ} \mathrm{C}$ to $-5^{\circ} \mathrm{C}$ was added to a well cooled solution of diphenylthiourea $(2 \mathrm{~g})$ in $20 \mathrm{~mL}$ chloroform. The solid obtained after evaporation of the solvent was washed with water and recrystallized to obtain cream colour crystal with $\mathrm{mp} 158^{\circ} \mathrm{C}$ and yield of $64 \%(1.28 \mathrm{~g})$. FT-IR (KBr) cm${ }^{-1}$ gave absorption bands at $1489.10\left(\mathrm{NH}_{2}\right), 1614.47$ (Aryl), 2067.67 (arylthiocyanate) and 2268.6 $(\mathrm{N}=\mathrm{C}-\mathrm{S})$. Proton spectrum $\left(\delta{ }^{1} \mathrm{H}\right): 7.57\left(\mathrm{CDCL}_{3}\right), \delta 2.59\left(\mathrm{NH}_{2}\right), \delta 3.73(\mathrm{CHX} 3$ of benzothiazole $\mathrm{H} 1)$ and $\delta 8.52(\mathrm{Ph}-\mathrm{H}) . \delta{ }^{13} \mathrm{C}: 39.77\left(\mathrm{CDCl}_{3}\right), 40.27-39.27$ (Benzothiazole-C), 80.12 (Ph-C). Analytical Calculated: for $\mathrm{C}_{13} \mathrm{H}_{10} \mathrm{~N}_{2} \mathrm{~S}: \mathrm{C}=68.99 ; \mathrm{H}=4.46 ; \mathrm{N}=12.38$; Found: $\mathrm{C}=68.43 ; \mathrm{H}=4.41 ; \mathrm{N}=12.57$.

\subsection{General Synthesis Of Benzothiazole Derivatives Of Sulphonamide}

A solution of 2-amino-6-phenylbenzothiazole $(0.01 \mathrm{~mol})$ in $25 \mathrm{~mL}$ of chloroform was added to a well stirred of sulphonyl chloride (0.01 mol) in $40 \mathrm{~mL}$ chloroform. The reaction mixture was refluxed for $30 \mathrm{~min}$. The chloroform was removed by evaporation and the residue treated with $30 \%$ dilute $\mathrm{HCl}$. The reaction mixture was boiled to $45^{\circ} \mathrm{C}$, decolourised with activated charcoal and filtered while hot. $0.2 \mathrm{M} \mathrm{NaHCO}$ was added to the filtrate while stirring and the completion of the reaction was ascertained by litmus paper showing neutral. The crude white product was filtered upon cooling, washed with methanol and recrystallized with 1:1 chloroform/methanol mixture.

\subsection{Synthesis Of N-(6-Biphenyl-1,3-Benzo[D]Thiazole-2-Yl)Benzenesulphonamide (3a)}

Molecular formula $\mathrm{C}_{19} \mathrm{H}_{14} \mathrm{~N}_{2} \mathrm{O}_{2} \mathrm{~S}_{2}$, weight 366.46(cal.), mp $234{ }^{\circ} \mathrm{C}$ and yield 68\% FT-IR (KBr) cm ${ }^{-1}: 1410.01$ (-SO $\mathrm{SO}_{2}$ ), 1591.33 (-NH), 1641.48 (Aryl) and 2023.40 $(\mathrm{N}=\mathrm{C}-\mathrm{S}) . \delta{ }^{1} \mathrm{H}: 2.51\left(\mathrm{CDCl}_{3}\right), 12.63(-\mathrm{NH}-), 3.60(2 \mathrm{CHd} \mathrm{J}=2.02), 3.62(1 \mathrm{CHs} \mathrm{J}=2.02), 7.63,7.60,7.59,7.57,7.55(5 \mathrm{CH}$. J = 3.01), 7.83, $7.81(2 \mathrm{CH} . \mathrm{J}=2.01)$, 8.06, 8.04, $8.02(3 \mathrm{CH} \mathrm{J}=1.00) . \delta^{13} \mathrm{C}: 44.27$ (phenothiazole carbons) 132.85-126.91 (Ph-C), $141.16(\mathrm{C}-\mathrm{N})$, and $170.70\left(\mathrm{C}-\mathrm{SO}_{2}\right)$. Analytical Calculated: for $\mathrm{C}_{19} \mathrm{H}_{14} \mathrm{~N}_{2} \mathrm{O}_{2} \mathrm{~S}_{2}: \mathrm{C}=62.69 ; \mathrm{H}=3.86 ; \mathrm{N}=7.47$; Found: $\mathrm{C}=62.71 ; \mathrm{H}=4.01 ; \mathrm{N}=7.46$.

\subsection{Synthesis of N-(6-Biphenyl-1,3-Benzo[D]Thiazole-2-Yl)-4-Methylbenzenesulphonamide (3b)}

Molecular formula $\mathrm{C}_{20} \mathrm{H}_{16} \mathrm{~N}_{2} \mathrm{O}_{2} \mathrm{~S}_{2}$, weight $380.48, \mathrm{mp} 210-212^{\circ} \mathrm{C}$ FT-IR $(\mathrm{KBr}) \mathrm{cm}^{-1}: 1440.87\left(-\mathrm{SO}_{2}\right), 1487.17(-\mathrm{NH}-), 1647.26(\mathrm{Ar})$ and $2108.27(\mathrm{~N}=\mathrm{C}-\mathrm{S}) . \delta^{1} \mathrm{H}$ : $2.51\left(\mathrm{CDCl}_{3}\right), 2.37-2.29(\mathrm{~J}=6.75,-\mathrm{CH} 3), 3.54-3.56(\mathrm{~J}=10.34$, of $3 \mathrm{X} \mathrm{CH}), 4.31(\mathrm{~J}=0.81 \mathrm{CHX} 2), 7.36,7.38(\mathrm{~J}=0.11 \mathrm{CHX} 2), 7.96,7.94,7.92(\mathrm{~J}=2.28 \mathrm{CHX} 3)$, 7.70, $7.67(\mathrm{~J}=4.35 \mathrm{CHX} 2) . \delta{ }^{13} \mathrm{C}: 21.41(\mathrm{CH} 3-\mathrm{C}), 44.23-72.62$ (phenothiazole-C) 126.79-143.08 (Ph-C), $170.53\left(\mathrm{C}-\mathrm{SO}_{2}\right)$ and 170.67 (C-N). Analytical Calculated: for $\mathrm{C}_{20} \mathrm{H}_{16} \mathrm{~N}_{2} \mathrm{O}_{2} \mathrm{~S}_{2}$ : $\mathrm{C}=63.13 ; \mathrm{H}=4.25 ; \mathrm{N}=7.36$; Found: $\mathrm{C}=63.02 ; \mathrm{H}=4.93 ; \mathrm{N}=7.21$. 


\subsection{Antibacterial Sensitivity Test Of Compounds}

The antibacterial activity of the synthesised compounds was determined using in vitro agar well diffusion technique as described by Adeniyi and Ayepola [12]. $0.1 \mathrm{~mL}$ culture of each bacteria strain (equivalent to $108 \mathrm{CFU} / \mathrm{mL}$ ) was used to inoculate the agar plates. The inoculated agar plates were appropriately labelled after drying and uniformed wells were bored in it using a plastic-cork borer of $6 \mathrm{~mm}$ diameter. $200 \mu \mathrm{L}$ of each test compound (20 mg/ml) was delivered into different wells with micropipette. Ampicillin was used as standard and was tested in the same manner. The plates were incubated at $37^{\circ} \mathrm{C}$ for $24 \mathrm{~h}$ and thereafter the diameters of zones of growth inhibition were measured with metre rule to the nearest millimetre.

Minimum inhibitory concentration (MICs) was determined by broth dilution technique as reported by Bonjar [13]. Different concentrations $(12.5,25,50$, $75,100,125,150,175,200 \mu \mathrm{g} / \mathrm{mL}$ ) of the test solution were evaluated. The lowest concentration that arrest the growth of bacteria was regarded as minimum inhibitory concentration (MIC).

\section{Results And Discussion}

\subsection{Chemistry}

The synthesis of both N-(biphenyl-4-yl)thiourea (1) and 2-amino-6-phenylbenzothiazole (2) was successfully achieved by following the reaction protocol of Saeed and cowokers [14]. The reaction of biphenylamine with ammonium thiocyanate at room temperature gave N-(biphenyl-4-yl)thiourea (1) (Scheme 1). Cyclization of the synthesised thiourea using freshly prepared mixture of bromine gas in chloroform gave a cream colour crystalline solid 2-amino-6phenylbenzothiazole (2) (Scheme 2).

Further reaction of the 2-amino-6-phenylbenzothiazole (2) with benzenesulphonyl chloride and p-toluenesulphonyl chloride was used to obtain N-(6phenyl-1, 3-benzothiazole -2-yl) benzenesulphonamide (3a) and N-(6-phenyl-1, 3-benzothiazole-2-yl) -4-methylbenzene sulphonamide (3b), respectively (Scheme 3). The structures of the synthesised compounds were confirmed by spectroscopic data of $I R,{ }^{1} \mathrm{H}$ and ${ }^{13} \mathrm{C}$ NMR as well as elemental analytical data.

The infrared spectra of the compounds gave the absorption bands of -N-S-C- at $2023.40-2265.47 \mathrm{~cm}^{-1}$, while the absorption bands of -SO ${ }_{2}$ - were observed at 1410.01-1440.01 $\mathrm{cm}^{-1}$ as expected. The vibration frequencies of 1614.47-1719.60 were attributed to the $\mathrm{C}=\mathrm{C}$ aromatic absorption bands. In the $\mathrm{H}^{1} \mathrm{NMR}^{-1}$ spectrum, all the three benzothiazole protons resonated at $\delta 3.54-3.73$ while protons of the phenyl moity attached to benzothiazole appeared at downfield region of $\delta$ 7.67-8.52 for compounds (3a) and (3b). The carbon NMR ${ }^{13} \mathrm{C}$ indicated the signals for phenothiazole at $\delta 39.27-40.27$ for compound (2) while the introduction of benzenesulphonyl chloride and para-toulenesulphonyl chloride to obtain compounds (3a) and (3b) shifted the phenothiazole carbons to $\delta$ 44.23-72.62. The carbon attached to $-\mathrm{SO}_{2}$ - were observed at downfield region at $\delta 170.67-170.70$ probably due to the high electronegative effect of $\mathrm{SO}_{2}$ - on the attached carbons.

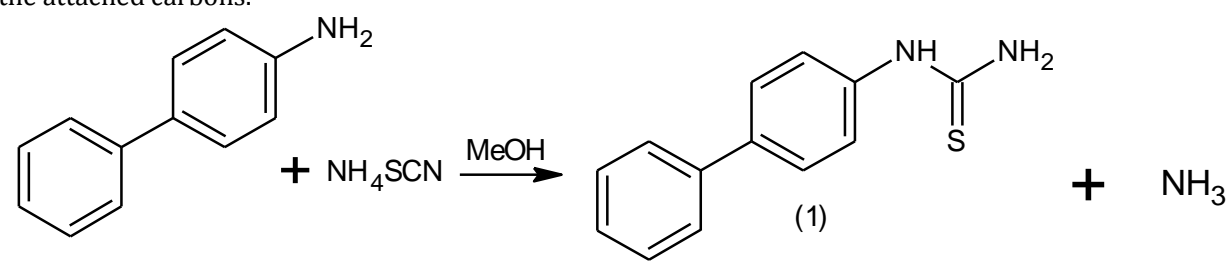

Scheme 1: Synthesis of N-biphenyl-4-yl thiourea (1)<smiles>NC(=S)Nc1ccc(-c2ccccc2)cc1</smiles>

Scheme 2: Synthesis of 2-Amino-6-phenylbenzothiazole (2)<smiles></smiles>

Scheme 3: Synthesis of benzothiazole derivatives of sulphonamide (3a \& 3b)

\subsection{Antibacterial Activity}

The antibacterial activities tested on S. aureus as Gram positive bacteria and E- coli as Gram negative bacteria are presented in Table 1 and Table 2. The screening of the synthesised compounds showed that some compounds inhibited the growth of both Gram negative and Gram positive bacteria organisms, only compound (2) showed inactive to the Gram negative organism Escherichia coli. Compound (3b) gave the best minimum inhibition concentration amongst the synthesised compounds, while the standard drug ampicillin showed better activities than the synthesised compounds. The possible mechanism of action of the synthesized compounds ( $3 a$ and $3 b$ ) could be the competitive inhibition of the enzyme dihydropteroate synthase that catalyze the reaction of p-aminobenzoic acid with 7,8-dihydro-6-hydroxymethylpterin-pyrophosphate to form dihydropteroic acid which is one of the steps in the formation of dihydrofolic acid [15]. The mechanism of action could be as well via the inhibition of carbonic anhydrase activities. Sulphonamides inhibits carbonic anhydrase and dihydropteroate synthase activities [5]. The mechanism of action of the thiourea (1) and benzothiazole (2) derivative could be through the inhibition of protein tyrosine kinases [5]. The compounds had reduced activities against the Gram negative organism (E. coli) and this could be attributed to the presence of efflux pump that reduce intracellular concentration of drug in Gram negative organism [16,17]. 
Table 1: Zone Of Inhibition Of Synthesized Compounds

\begin{tabular}{llllll}
\hline & \multicolumn{2}{c}{ Zone of inhibition (mm) } & & \\
Organism & Compd 1 & Compd 2 & Compd 3a & Compd 3b & Ampicillin \\
\hline Staphylococcus aureus & 16.00 & 17.00 & 28.00 & 18.00 & 3200 \\
Escherichia coli & 8.00 & - & 17.00 & 20.00 & 24.00 \\
\hline
\end{tabular}

Compd = Compound

Table 2: Minimum Inhibitory Concentration Of The Synthesized Compounds

\begin{tabular}{llcccc}
\hline \multirow{2}{*}{ Organisms } & \multicolumn{2}{c}{ Minimum inhibition concentration $(\mu \mathrm{g} / \mathrm{mL})$} & \multicolumn{2}{c}{ Compd 3b } & Ampicillin \\
\hline Staphylococcus aureus & Compd 1 & Compd 2 & Compd 3a & Comp.0 \\
Escherichia coli & $>75.00$ & $<75.00$ & 50.00 & $<50.00$ & 25.00 \\
& $>100.00$ & - & $>50.00$ & $<50.00$ & 12.50 \\
\hline
\end{tabular}

Compd = Compound

\section{Conclusion}

Benzothiazole derivatives of sulphonamides with anti-bacteria properties were synthesised from thiourea with good yields. The synthesis of the targeted benzene sulphonamide and para-toulenesulphonamide were successfully achieved by cyclization of thiourea (1) to obtained benzothiazole (2) which reacted with benzenesulphonyl chloride and para-toulenesulphonyl chloride to give bezenesulphonamide (3a) and para-toulenesulphonamide ( $3 \mathrm{~b}$ ). The compounds showed good antibacterial properties on Staphylococcus aureus and Escherichia coli except 2-amino-6-phenylbenzothiazole that showed no activity against Eschericia coli. We recommend further studies to evaluate the toxicity and mechanism of action of the antibacterial activities of the compounds.

\section{Acknowledgments}

The authors are grateful to the management and technical staff of National Research Institute for Chemical Technology Zaria (NARICT), Central Laboratory of Kwame Nkrummah University of Science and Technology Ghana, Central Drug Research Institute Lucknow India, for their assistance in the characterization of the compounds. We also appreciate the support of the technical staff of Department of Chemistry and Department of Microbiology, Imo state University.

\section{References}

[1], F. Prestinaci, P. Pezzotti, A. Pantosti, “Antimicrobial resistance: a global multifaceted phenomenon. Pathogens and Global Health, 2015, 109(7), 309318". https://doi.org/10.1179/2047773215Y.0000000030

[2] World Health Organisation. Antimicrobial resistance: Fact sheet. .2018. www.who.int/en/news-room/fact-sheets/detail/antimicrobial-resistance

[3] D. S. Doğruer, S. Urlu, T. Önkol, B. Özçelik, M. F. Şahin, "Synthesis of some pyridazine derivatives carrying urea, thiourea, and sulfonamide moieties and their antimicrobial activity", Turkish Journal of Chemistry, Vol. 34(1), pp. 57-65. 2010. doi:10.3906/kim-0904-27

[4] World Health Organisation, Global Framework for Development \& Stewardship to Combat Antimicrobial Resistance Draft Roadmap. 2017. www.who.int/antimicrobial-resistance/global-action-plan/UpdatedRoadmap-Global-Framework-for-Development-Stewardship-tocombatAMR_2017_11_03.pdf?ua=1

[5] M. M. Ghorab, M. S. Alsaid, M. S. El-Gaby, M. M. Elaasser, Y. M. Nissan, "Antimicrobial and anticancer activity of some novel fluorinated thiourea derivatives carrying sulfonamide moieties: synthesis, biological evaluation and molecular docking", Chemistry Central Journal, Vol. 11(1), pp. 32, 2017. https://doi.org/10.1186/s13065-017-0258-4

[6] A. P. Keche, G. D. Hatnapure, R. H. Tale, A. H. Rodge, S. S. Birajdar, V. M. A Kamble, "Novel pyrimidine derivative with aryl urea, thiourea and sulfonamide moieties: synthesis, anti-inflammatory and antimicrobial evaluation." Bioorganic \& Medicinal Chemistry Letters, vol. 22(10), pp. 3445-3448. 2012. https://doi.org/10.1016/j.bmcl.2012.03.092

[7] J. N. Domínguez, C. León, J. Rodrigues, N. G. de Domínguez, J. Gut, P.J. Rosenthal, "Synthesis and antimalarial activity of sulfonamide chalcone derivatives," Il Farmaco, 60(4), pp. 307-311. 2005. https://doi.org/10.1016/j.farmac.2005.01.005

[8] I. R. Ezabadi, C. Camoutsis, P. Zoumpoulakis, A. Geronikaki, M. Soković,, J. Glamočilija, A. Ćirić. "Sulfonamide-1, 2, 4-triazole derivatives as antifungal and antibacterial agents: Synthesis, biological evaluation, lipophilicity, and conformational studies," Bioorganic \& Medicinal Chemistry, Vol.16(3), pp. 11501161. 2008. https://doi.org/10.1016/j.bmc.2007.10.082

[9] Y. Luo, K. M. Qiu, X. Lu, K. Liu, J. Fu, H. L. Zhu, "Synthesis, biological evaluation, and molecular modeling of cinnamic acyl sulfonamide derivatives as novel antitubulin agents," Bioorganic \& Medicinal Chemistry, Vol. 19(16), pp. 4730-4738. https://doi.org/10.1016/j.bmc.2011.06.088

[10] R. S. Keri, M. R. Patil, S. A. Patil, S. A. Budagumpi, "Comprehensive review in current developments of benzothiazole-based molecules in medicinal chemistry,” European Journal of Medicinal. Chemistry, Vol. 89, pp. 207-251, 2015. https://doi.org/10.1016/j.ejmech.2014.10.059

[11] I. C. Chinaka, O. S. Okwudili, D. A. Nkiru, "Chemical Composition, Antioxidant and Antibacterial Properties of Chloroform Fraction of Platycerium Bifurcatum," Advanced Research in Life Sciences, Vol. 2(1), pp. 1-6, 2018.

[12] B. A. Adeniyi, O. O. Ayepola, "The phytochemical screening and antimicrobial activity of leaf extracts of Eucalyptus camaldulensis and Eucalyptus torelliana (Myrtaceae)," Research Journal of Medicinal Plant, Vol. 2(1), pp. 34-38. 2008

[13] G. S. Bonjar, "New approaches in screening for antibacterials in plants, “ Asian Journal of Plant Sciences, Vol. 3, pp. 55-60. 2004.

[14] S. Saeed, N. Rashid, P. G. Jones, M. Ali, R. Hussain, "Synthesis, characterization and biological evaluation of some thiourea derivatives bearing benzothiazole moiety as potential antimicrobial and anticancer agents," European Journal of Medicinal Chemistry, Vol. 45(4), pp. 1323-1331, 2010. https://doi.org/10.1016/j.ejmech.2009.12.016

[15] 0. Sköld, "Sulfonamide Resistance: Mechanism and Trends. Drug Resistance Updates," Vol. 3(3), pp. 155-160, 2000. doi: 10.1054/drup.2000.0146

[16] D. Du, Z. Wang, N. R. James, J. E. Voss, E. Klimont, T. Ohene-Agyei, H. Venter, W. Chiu, B. F. Luisi, "Structure of the AcrAB-TolC multidrug efflux pump," Nature, Vol. 509(7501), pp. 512-515, 2014.doi:10.1038/nature13205

[17] X. Z. Li, P. Plésiat, H. Nikaido, “The challenge of efflux-mediated antibiotic resistance in Gram-negative bacteria," Clinical Microbiology Reviews, Vol. 28(2), pp. 337-418. 2015. doi:10.1128/CMR.00117-14. 